\title{
Multifactorial control of water and saline intake: role of $\alpha_{2}$-adrenoceptors
}

L.A. De-Luca Jr. and J.V. Menani

\author{
Departamento de Ciências Fisiológicas, Faculdade de Odontologia, \\ Universidade Estadual Paulista, 14801-903 Araraquara, SP, Brasil
}

\begin{abstract}
Correspondence
L.A. De Luca Jr.

Departamento de Ciências

Fisiológicas

Faculdade de Odontologia

Universidade Estadual Paulista

14801-903 Araraquara, SP

Brasil

Fax: 55 (016) 222-4823

Presented at the International Symposium "Neuroendocrine Control of Body Fluid Homeostasis", Ribeirão Preto, SP, Brasil,

August 17-20, 1996.

Research supported by CNPq,

FAPESP and FUNDUNESP.
\end{abstract}

Received November 29, 1996 Accepted January 6, 1997

\section{Mechanisms of hydrosaline intake and their inhibition by clonidine, an $\alpha_{2}$-adrenoceptor agonist}

Water and sodium intake are ingestive behaviors important for the control of body fluid homeostasis. Both behaviors are critical for correcting the reduction in extracellular fluid volume, and water intake is also important for the correction of intracellular dehydration that ensues during an increase in body fluid osmolality.

The double-depletion hypothesis considers the water intake of water-deprived animals to be activated by a combination of signals derived from both intracellular and extracellular dehydration, which activates two separate pathways dependent on osmoreceptors and angiotensin II (ANG II), respectively (1). The osmotic pathway is probably dependent on central acetylcholine (2). The inhibition of water intake dependent on each pathway by the $\alpha_{2}$-adrenergic agonist clonidine has suggested that both pathways converge to a final common pathway $(3,4)$. Some of the many different forms of induction of water intake related to each pathway and inhibited by clonidine acting in the brain include increase in blood osmolality by administration of hypertonic solutions, direct cholinergic activation, direct angiotensinergic activation, and water deprivation (5-7). Meal-dependent water intake, which involves peripheral histamine (8) and probably central cholinergic receptors (9), is also inhibited by clonidine (10). Thus, clonidine is a ubiquitous inhibitor of thirst-inducing mechanisms. This inhibition is mediated by central $\alpha_{2}$-adrenergic receptors since it is antagonized by the $\alpha_{2}$-adrenergic antagonists yo- 
himbine and idazoxan injected into the brain (5,11-13). Prazosin, an $\alpha_{1}$-adrenergic antagonist, also inhibits the effect of clonidine $(5,12,13)$, but it can also bind to $\alpha_{2}$-adrenergic receptors (14). This observation, together with the effects of yohimbine and idazoxan, suggests that the receptors on which clonidine acts to inhibit water intake include $\alpha_{2}$ prazosin-binding sites.

The control of salt intake in the form of saline solution also involves more than one mechanism. Sodium depletion and the consequent volume contraction activate hormonal and sensory signals that in turn activate the central circuits of saline intake. These signals include ANG II and aldosterone (15) and reduction in the load of cardiovascular pressor receptors (16). The release of ANG II and reduction in the activity of pressor receptors are also involved in the activation of water intake (16). If sodiumdepleted animals have access to water, reduction in blood osmolality also occurs, which in turn inhibits the central release of oxytocin, a component of inhibitory mechanisms of saline intake (17). Another form of saline intake is that expressed by normovolemic and normosodic animals. This intake is characteristically non-regulatory since it occurs in non-depleted animals. Its basis has not been systematically explored, but an interesting hypothesis is that it is controlled like circadian behaviors dependent on en-

Table 1 - Models of water and saline intake inhibited by clonidine.

Each model corresponds to at least one mechanism that induces water or saline intake and is inhibited by clonidine acting in the brain. Numbers in parentheses indicate the reference for each model in the text.

\begin{tabular}{ll} 
Water intake & \multicolumn{1}{c}{ Saline intake } \\
\hline Water deprivation $(5,6,10,12,13)$ & Sodium depletion $(10,13,22)$ \\
Cholinergic activation $(6,7)$ & Water deprivation $(22)$ \\
Angiotensin II $(4,6,11,42)$ & Angiotensin II (21) \\
Cell dehydration (6) & Mineralocorticoid (21) \\
Meal associated (10) & Non-regulatory (need-free) (22)
\end{tabular}

dogenous clocks (18). Finally, saline intake is also induced by water deprivation (19), and although the mechanism is still not fully described, it probably involves ANG II (20). Interestingly, all these forms of saline intake are also inhibited by clonidine $(10,21,22)$. This inhibition is also dependent on $\alpha_{2}$-adrenoceptors since it is antagonized by idazoxan and prazosin $(13,22)$. The different models of water and saline intake inhibited by clonidine are listed in Table 1.

The mechanisms of action of clonidine on fluid intake involve at least the activation of $\alpha_{2}$-adrenergic receptors as discussed above. The circuit that mediates this inhibition is very probably specific for the behavior of water and saline intake since it is preferential for these forms of intake compared to solid food or sucrose solution $(5,10)$. Other possible mechanisms are currently under investigation in our laboratory. Preliminary results suggest that the inhibition depends, at least in part, on the reduction of endogenous release of noradrenaline (23). Clonidine injected centrally also induces alterations in arterial pressure, but these alterations are not related to the inhibition of hydrosaline intake because similar alterations in arterial pressure are induced by other compounds, such as carbachol or isoproterenol, which do not affect water or saline intake $(10,22)$. Another effect of clonidine is the induction of systemic release of atrial natriuretic peptide (ANP) (24). Interestingly, central ANP also inhibits water and saline intake (25), and, like central oxytocin, mediates osmotic inhibition of salt intake (26). An increase in blood ANP concentration is probably not the mediator of inhibition of fluid intake induced by clonidine since central cholinergic activation also induces the release of ANP (27), but this activation does not alter saline intake of water-deprived rats (20). Yet, a participation of ANP of central origin as a mediator of the effect of clonidine is a possibility to be tested. 


\section{A multifactorial model for dehydra- tion-induced hydrosaline intake}

One implication of the effects of clonidine on saline intake is that the concept of a final common pathway inhibited by $\alpha_{2}$-adrenoceptors $(3,4)$ should include this behavior. However, since water intake and saline intake are distinct behaviors, it is not possible to assume a final common pathway for both of them. Therefore, there must be two central circuits that are activated by different types of dehydration and inhibited by $\alpha_{2^{-}}$ adrenoceptors, one for the control of water and the other for the control of saline intake. As mentioned above, these circuits share the activation by ANG II and by volume receptors during extracellular dehydration $(1,15,16)$, but one (water) is activated $(1,28,29)$ and the other (saline) is inhibited $(17,30,31)$ by the increase in osmolality or in sodium concentration. Furthermore, aldosterone release activated by ANG II during extracellular depletion but inhibited by the increase in osmolality (32) acts synergistically with ANG II in the brain to induce saline intake (15), in spite of the controversy on whether central or systemic ANG II is important for saline intake (15,33-36). Finally, the unloading of volume receptors probably removes the inhibition that hindbrain structures exert on water and saline intake $(16,37,38)$. Every mechanism so far tested (Table 1) that induces water and saline intake is inhibited by clonidine. Therefore, these two behaviors share a common inhibitory factor represented by $\alpha_{2}$-adrenoceptors. The wire-block diagram shown in Figure 1 summarizes the connections between the multiple factors that control water and saline intake resulting from dehydration, and their relation to $\alpha_{2}$-adrenoceptors in the rat. The central circuits that control water and saline intake are represented separately, each corresponding to one summing point of multiple factors (variables) that con-

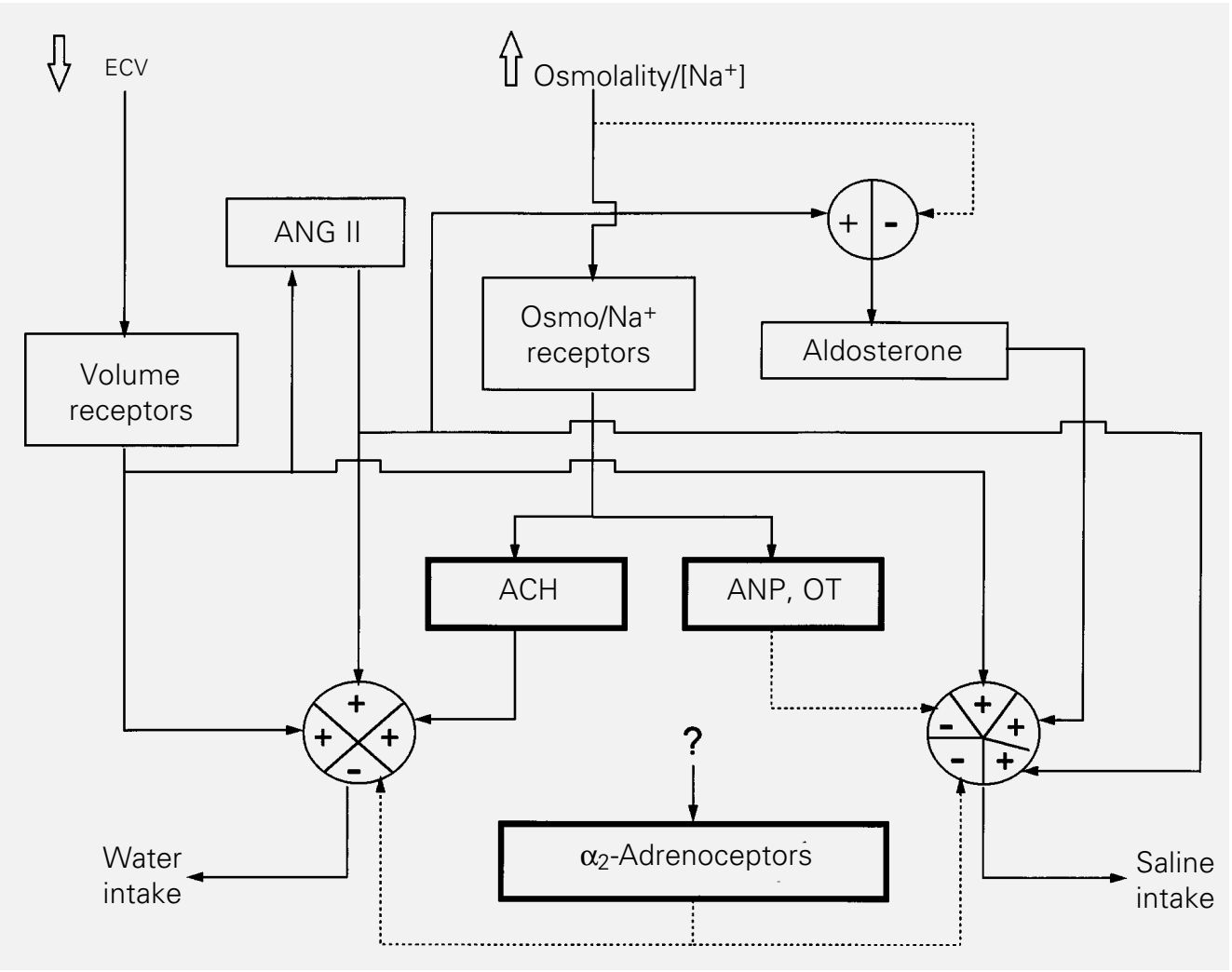

Figure 1 - Multifactorial blockdiagram model of the control of water and saline intake. Central circuits that control water and saline intake and integrate the multiple inhibiting and activating factors described in the literature are represented by summing points (see text for references and discussion). Bold lines indicate central factors. Dotted lines indicate inhibiting and continuous lines indicate activating factors. Indents indicate bypass points. ECV, Extracellular volume; $\mathrm{ACH}$, acetylcholine; ANP, atrial natriuretic peptide; OT, oxytocin; ANG II, angiotensin II (either central or peripheral). 
trol each respective behavior. A summing point in the block diagram is represented by a circle receiving inputs from variables that can be added to or subtracted from the others (39). The central core of the diagram is the $\alpha_{2}$-adrenoceptor as a subtraction factor common to both summation points. The diagram of course does not intend to be definitive and still has points to be confirmed or modified. A question mark in the model exemplifies an important part to be understood, i.e., the mechanism of activation of $\alpha_{2}$-adrenoceptors in physiological situations. The diagram also does not include non-regulatory intakes or distinguish between central and peripheral ANG II acting in the brain.

\section{Importance of the $\alpha_{2}$-adrenoceptors for the understanding of the role of noradrenaline in hydrosaline intake}

The effects of clonidine described above suggest that endogenous noradrenaline acts on $\alpha_{2}$-adrenoceptors belonging to central inhibitory circuits that control water and saline intake. Noradrenaline injected into the brain inhibits water intake $(10,40,41)$, but is also considered to be important for the activation of these behaviors.

Early studies have suggested opposite actions for alpha- and beta-receptors on wa- ter intake, the first inhibiting and the second activating this behavior (41). Recently, a dual role for noradrenaline in water intake was proposed based on the opposite effects alpha-adrenergic antagonists (yohimbine or prazosin) had on water intake (42). When water intake was induced by water deprivation, yohimbine or prazosin inhibited the antidipsogenic effect of clonidine, but neither one injected alone altered water intake (5). When water intake was induced by ANG II, yohimbine or prazosin induced an inhibition of the behavior which was potentiated by clonidine (42). This potentiation suggests that clonidine and the antagonists act on receptors located at different sites and, therefore, that noradrenaline participates in one site that inhibits and in another that activates water intake. The importance of noradrenaline for the activation of water intake is confirmed by other studies utilizing alphaantagonists or destruction of noradrenergic terminals (43-46).

Saline intake is also inhibited $(10,21)$ or activated by noradrenaline (47). Thus, this double mediation of the control of water and saline intake by noradrenaline is explained by the dual-role hypothesis which proposes that central noradrenaline participates in the inhibition and activation of both behaviors $(10,42,48)$.

\section{References}

1. Epstein AN (1973). Epilogue: retrospect and prognosis. In: Epstein AN, Kissilef HR \& Stellar E (Editors), The Neuropsychology of Thirst: New Findings and Advances in Concepts. Wiley, New York, 315-332.

2. Block ML \& Fisher AE (1970). Anticholinergic central blockade of salt-aroused and deprivation-induced drinking. Physiology and Behavior, 5: 525-527.

3. Fregly MJ \& Rowland NE (1986). Role for $\alpha_{2}$-adrenoceptors in experimentally-induced drinking in rats. In: de Caro G, Epstein AN \& Massi M (Editors), The Physiology of Thirst and Sodium Appetite. Plenum Press, New York, 509-519.
4. Wilson KM, Rowland $N$ \& Fregly MJ (1984). Drinking: a final common pathway? Appetite, 5: 31-38.

5. Ferrari AC, Camargo LAA, Saad WA, Renzi A, De Luca Jr LA \& Menani JV (1990). Clonidine and phenylephrine injected into the lateral hypothalamus inhibit water intake in rats. Brain Research, 522: 125130.

6. Fregly MJ, Kelleher DL \& Greenleaf JE (1981). Antidipsogenic effect of clonidine on angiotensin II-, hypertonic saline-, pilocarpine- and dehydration-induced water intakes. Brain Research Bulletin, 7: 661664.
7. Leite DF, Camargo LAA, Saad WA, Renzi A, Fóglia S, De Luca Jr LA \& Menani JV (1992). Role of adrenergic and cholinergic pathways of the medial septal area in the control of water intake and renal excretion in rats. Pharmacology, Biochemistry and Behavior, 26: 203-210.

8. Kraly FS (1990). Drinking elicited by eating. Progress in Psychobiology and Physiological Psychology, 14: 67-133.

9. De Luca Jr LA, Diniz DLWP \& AntunesRodrigues J (1988). Effect of atropine injection into the medial septal area on foodassociated drinking. Brazilian Journal of Medical and Biological Research, 21: 573575. 
10. Yada MM, de Paula PM, Menani JV \& De Luca Jr LA (1996). Central alpha-adrenergic agonists and need-induced $3 \% \mathrm{NaCl}$ and water intake. Pharmacology, Biochemistry and Behavior (in press).

11. Fregly MJ, Rowland NE \& Greenleaf JE (1984). Clonidine antagonism of angiotensin-related drinking: a central site of action. Brain Research, 298: 321-327.

12. Callera JC, Camargo LAA, De Luca Jr LA, Menani JV, Renzi A \& Saad WA (1993). Clonidine and phenylephrine injected into the lateral preoptic area reduce water intake in dehydrated rats. Pharmacology, Biochemistry and Behavior, 46: 39-43.

13. Yada MM, de Paula PM, Menani JV, Renzi A, Camargo LAA, Saad WA \& De Luca Jr LA (1996). Receptor-mediated effects of clonidine on need-induced $3 \% \mathrm{NaCl}$ and water intake. Brain Research Bulletin (in press).

14. Nahorski SR, Barnett DB \& Cheung YD (1985). $\alpha$-Adrenoceptor-effector coupling: affinity states or heterogeneity of the $\alpha_{2}$ adrenoceptor? Clinical Science, 68: 39s42s.

15. Epstein AN (1991). Neurohormonal control of salt intake in the rat. Brain Research Bulletin, 27: 315-320.

16. Johnson AK \& Thunhorst RL (1995). Sensory mechanisms in the behavioral control of body fluid balance: thirst and salt appetite. Progress in Psychobiology and Physiological Psychology, 16: 145-176.

17. Verbalis JG, Blackburn RE, Olson B \& Stricker EM (1993). Central oxytocin inhibition of food and salt ingestion: a mechanism for intake regulation of solute homeostasis. Regulatory Peptides, 45: 149154.

18. Epstein AN (1990). Prospectus: thirst and salt appetite. In: Stricker EM (Editor), Handbook of Behavioral Neurobiology. Vol. 10. Neurobiology of Fluid and Fluid Intake. Plenum Press, New York, 489-512.

19. Weisinger RS, Denton DA, McKinley MJ \& Nelson JF (1985). Dehydration-induced sodium appetite in rats. Physiology and Behavior, 34: 45-50.

20. Sato MA, Yada MM \& De Luca Jr LA (1996). Antagonism of the renin-angiotensin system and water deprivation-induced $\mathrm{NaCl}$ intake in rats. Physiology and Behavior, 60: 1099-1104.

21. de Paula PM, Sato MA, Menani JV \& De Luca Jr LA (1996). Effects of central $\alpha$ adrenergic agonists on hormone-induced $3 \% \mathrm{NaCl}$ and water intake. Neuroscience Letters, 214: 155-158.
22. Sato MA, Yada $M M$, Renzi $A$, Camargo LAA, Saad WA, Menani JV \& De Luca Jr LA (1996). Antagonism of clonidine injected intracerebroventricularly in different models of salt intake. Brazilian Journal of Medical and Biological Research, 29: 1663-1666

23. da Silva RM, Renzi A, Menani JV \& De Luca Jr LA (1996). Pre-synaptic action of central clonidine on water intake. XI Annual Meeting of the Federação de Sociedades de Biologia Experimental, 133 (Abstract).

24. Baranowska B, Gutkowska J, Cantin M \& Genest J (1987). Plasma immunoreactive atrial natriuretic factor (IR-ANF) increases markedly after alpha-2 adrenergic stimulation with clonidine in normally-hydrated rats. Biochemical and Biophysical Research Communications, 143: 159-163.

25. Antunes-Rodrigues J, McCann SM \& Samson WK (1986). Central administration of atrial natriuretic factor inhibits saline preference in the rat. Endocrinology, 118: 1726-1728.

26. Blackburn RE, Samson WK, Fulton RJ, Stricker EM \& Verbalis JG (1995). Central oxytocin and ANP receptors mediate osmotic inhibition of salt appetite in rats. American Journal of Physiology, 269: R245-R251.

27. Baldissera S, Menani JV, Turrin MQA, Sotero dos Santos LS, Favaretto AL, Gutkowska J, McCann SM \& AntunesRodrigues J (1989). Role of the hypothalamus in the control of atrial natriuretic peptide release. Proceedings of the National Academy of Sciences, USA, 86: 96219625.

28. Fitzsimons JT (1989). Bengt Andersson's pioneering demonstration of the hypothalamic "drinking area" and the subsequent osmoreceptor/sodium receptor controversy. Acta Physiologica Scandinavica, 136 (Suppl 583): 15-25.

29. McKinley M (1992). Common aspects of the cerebral regulation of thirst and renal sodium excretion. Kidney International, 41: S102-S106.

30. Chiaraviglio E \& Pérez Guaita MF (1986). The effect of intracerebroventricular hypertonic infusion on sodium appetite in rats after peritoneal dialysis. Physiology and Behavior, 37: 695-699.

31. Weisinger RS, Considine P, Denton DA, McKinley MJ \& Mouw D (1979). Rapid effect of change in cerebrospinal fluid sodium concentration on salt appetite. $\mathrm{Na}$ ture, 280: 490-492.

32. Schneider EG (1991). In water deprivation, osmolality becomes an important determinant of aldosterone secretion. News in Physiological Sciences, 5: 197-201.
33. Sakai RR, Chow SY \& Epstein AN (1990). Peripheral angiotensin II is not the cause of sodium appetite in the rat. Appetite, 15: 161-170.

34. Yang Z-F \& Epstein AN (1991). Bloodborne and cerebral angiotensin and the genesis of salt intake. Hormones and Behavior, 25: 461-476.

35. Thunhorst RL \& Fitts DA (1994). Peripheral angiotensin causes sodium appetite in rats. American Journal of Physiology, 267: R171-R177.

36. Rowland NE, Rozelle A, Riley PJ \& Fregly MJ (1992). Effect of nonpeptide angiotensin receptor antagonists on water intake and salt appetite in rats. Brain Research Bulletin, 29: 389-393.

37. Menani JV, Beltz TG \& Johnson AK (1995). Effects of lidocaine injection into the parabrachial nucleus on dipsogenic and pressor responses to central angiotensin II in rats. Brain Research, 695: 250252.

38. Menani JV, Thunhorst RL \& Johnson AK (1996). Lateral parabrachial nucleus and serotonergic mechanisms in the control of salt appetite in rats. American Journal of Physiology, 270: R162-R168.

39. Riggs DS (1974). Control Theory and Physiological Feedback Mechanisms. Williams and Wilkins Co., New York.

40. Grossman SP (1962). Direct adrenergic and cholinergic stimulation of hypothalamic mechanisms. American Journal of Physiology, 202: 872-882.

41. Leibowitz SF (1971). Hypothalamic alphaand beta-adrenergic systems regulate both thirst and hunger in the rat. Proceedings of the National Academy of Sciences, USA, 68: 332-334.

42. Ferrari AC, Camargo LAA, Saad WA, Renzi A, De Luca Jr LA \& Menani JV (1991). Role of the alpha1- and alpha2-adrenoceptors of the lateral hypothalamus in the dipsogenic response to central angiotensin II in rats. Brain Research, 560: 291296.

43. Jones DL (1988). Hypothalamic alpha-adrenergic blockade modifies drinking and blood pressure responses to central angiotensin II in conscious rats. Canadian Journal of Physiology and Pharmacology, 66: 1270-1277.

44. Cunningham JT \& Johnson AK (1991). The effects of central norepinephrine infusions on drinking behavior induced by angiotensin after 6-hydroxydopamine injections into the anteroventral region of the third ventricle. Brain Research, 558: 112116. 
45. Andersson B, Leksell LG, Lishajko F \& Rundgren M (1978). Cerebral sodium-noradrenaline interaction: dipsogenic, antidiuretic and natriuretic effects. Acta Physiologica Scandinavica, 102: 254-256.
46. Barbosa SP, de Gobbi JIF, Zilioli L, Camargo LAA, Saad WA, Renzi A, De Luca Jr LA \& Menani JV (1995). Role of cholinergic and adrenergic pathways of the medial septal area in the water intake and pressor response to central angiotensin II and carbachol in rats. Brain Research Bulletin, 37: 463-466.
47. Chiaraviglio E (1976). Angiotensin-norepinephrine interaction on sodium intake. Behavioral Biology, 17: 411-416.

48. De Luca Jr LA, Camargo LAA, Menani JV Renzi A \& Saad WA (1994). On a possible dual role for central noradrenaline in the control of hydromineral fluid intake. Brazilian Journal of Medical and Biological Research, 27: 905-914. 